\title{
Relationships between water transparency and abundance of Cynodontidae species in the Bananal floodplain, Mato Grosso, Brazil
}

\author{
Cesar Enrique de Melo, Jane Dilvana Lima and Eliete Francisca da Silva
}

The Cerrado in the Central Brazil is currently one of the most threatened ecosystems in the world. As a result, the aquatic habitats in this biome also undergo great impacts. Alterations related to land-use change increase sediment loadings in rivers, streams and lakes, resulting in sedimentation and decrease in water transparency. Water transparency determines underwater visibility conditions, and as a consequence fish assemblages respond to spatial and temporal changes in this variable. This work aimed to examine the influence of transparency on the abundance and distribution of Cynodontidae species, a visually oriented predatory fish group. Fish sampling was conducted in 15 sites located between Mortes and Araguaia rivers in the Bananal floodplain, Mato Grosso State. Regression analysis between relative abundance of Cynodontidae (in number of individuals and biomass) and water transparency showed a positive and highly significant correlation, indicating that this group shows species-specific habitat affinities for clearer waters. These results suggest that the increase in water turbidity in this region can affect the patterns of abundance and distribution of the Cynodontidae species, as well as other visually oriented fishes.

O cerrado do Brasil Central é atualmente um dos ecossistemas mais ameaçados do mundo. Em consequência, os ambientes aquáticos desse bioma também sofrem grandes impactos. Alterações relacionadas a mudanças no uso da terra aumentam a descarga de sedimentos em rios, córregos e lagos, resultando em processos de assoreamento e diminuição da transparência da água. A transparência da água determina as condições de visibilidade subaquáticas, e em consequência os peixes respondem às variações espaciais e temporais desta variável. O objetivo deste trabalho foi verificar a influência da transparência da água na abundância e distribuição de peixes da família Cynodontidae, um grupo de peixes predadores que se orientam visualmente. As coletas de peixes foram realizadas em 15 ambientes localizados na região entre o rio das Mortes e rio Araguaia, na planície do Bananal, Estado do Mato Grosso. As análises de regressão entre a abundância relativa de Cynodontidae (em número de indivíduos e biomassa) e a transparência da água mostraram uma correlação positiva e significante, o que indica que este grupo apresenta afinidade de hábitat por águas mais claras. Esses resultados sugerem que o aumento na turbidez das águas nesta região pode afetar os padrões de abundância e distribuição das espécies de Cynodontidae, bem como de outras espécies de peixes visualmente orientadas.

Key words: Fish ecology, Cerrado, Central Brazil, Conservation, Araguaia.

\section{Introduction}

The Cerrado biome in the Central Brazil is one of the most altered ecosystems in the world (Mittermeier et al., 1999; Silva \& Bates, 2002). The advance of the agricultural and cattle ranching frontier since the 1970s has caused a marked fragmentation of the Cerrado, transforming the native landscape into extensive fields of grass pasture, soybean and corn (Fearnside, 2001; Le Bourlegat, 2003; Klink \&
Machado, 2005; Silva et al., 2006). Land-use changes and deforestation causes serious alterations to aquatic habitats (Souza, 1994; Wantzen, 2006; Wantzen et al., 2006), including siltation and increase in water turbidity (Neill et al., 2001; Pusey \& Arthington, 2003).

Siltation effects, such as habitat destruction and homogenization, are pointed out as a major threat to some Brazilian river basins (Agostinho et al., 2005). Increasing water turbidity and consequently decreasing transparency has

Laboratório de Ictiologia e Limnologia, Depto. de Ciências Biológicas, Universidade do Estado de Mato Grosso - UNEMAT, Campus de Nova Xavantina, BR 158 km 655, 78690-000 Nova Xavantina, MT, Brazil. meloce@yahoo.com (CEM) 
several effects on fish fauna composition and structure (Henley et al., 2000; Lin \& Caramaschi, 2005). These growing environmental problems are intensified by the paucity of studies on fish fauna in this biome, especially in Mato Grosso, the Brazilian state which holds the larger extension of nonmodified Cerrado areas (Silva et al., 2006). Studies aiming to evaluate the impacts of land-use change on the Cerrado water bodies are still not enough to determine to what extent fish communities are being affected by this process. Nevertheless, habitat alteration can put at risk the complex evolutionary relationship between the Cerrado and the fishes of its rivers, streams and lakes (Melo et al., 2003, 2004).

In the last decade, studies conducted in tropical floodplains have indicated that water transparency is a good predictor of fish assemblage composition and distribution (Tejerina-Garro et al., 1998; Pouilly \& Rodríguez, 2004), through an interaction between underwater visibility conditions and species foraging adaptations, as stated in the piscivory-transparency-morphometry (PTM) model proposed by Rodríguez \& Lewis (1997). These studies demonstrate that spatial and temporal variations in water transparency are followed by changes in the abundance and distribution of the main fish orders according to their dependence on vision.

The characiform family Cynodontidae is an important piscivorous fish group, represented mostly by species adapted to visual hunting (Goulding, 1980). For that reason, it is expected that the patterns of distribution and abundance of this family may vary along a gradient of spatially variable visibility conditions. In this study the abundance and distribution of four Cynodontidae species in relation to water transparency was examined in 15 lotic and lentic habitats within the Bananal floodplain. Spatial niche breadth and main prey items were also reported for each species. Describing the relationships between fish and environmental variables is important in these habitats subject to growing alterations, and it is essential to the elaboration of conservation plans for the Cerrado region in Central Brazil.

\section{Material and Methods}

\section{Study area}

The Bananal floodplain is a large area of approximately $59,000 \mathrm{~km}^{2}$ (Hamilton et al., 2002) located in the Central Brazil and drained by the rios Araguaia and Mortes (Diegues, 2002).

The predominant vegetation is the Cerrado (savanna), but it comprises a wide variation in physiognomies (Marimon \& Lima, 2001). The riparian forest is flooded partial or completely during the inundation season. Extensive cattle ranching is the predominant activity in the region, but it is restricted to better-drained areas. Sampling was conducted in 15 sites located within the floodplain: 5 rivers (Cristalino, São João Grande, Araguaia, Riozinho and Mortes) and 10 oxbow lakes (Cocho, Sucupira, Aruanã, Kênia, Lagoão, Melancia, Redondo, Baião, Baia da Saudade and Beleza) (Fig. 1). Sites were selected based on accessibility and location on the floodplain. Eight of the sampling sites are situated within the Araguaia State Park, a conservation area with 2,204 $\mathrm{km}^{2}$, located between the rios Araguaia and Mortes.

\section{Sampling Methodology}

Fish sampling was conducted in dry season periods from 1998 to 2004. Fishes were sampled with gillnets ( $10 \mathrm{~m} \mathrm{x} 2 \mathrm{~m}$ ) of several mesh sizes ( $3,4,5,6,7,8,10,12,14$, and $18 \mathrm{~cm}$ between opposite knots). In each standardized sampling effort, gillnets were deployed for 24 consecutive hours and checked at every four hours. Each site was sampled only once. All captured specimens were deposited in the fish collection of the Laboratório de Ictiologia e Limnologia of the Universidade do Estado de Mato Grosso (LILUNX). Water transparency was measured once per site using a Secchi disk near the location where gillnets were deployed.

\section{Diet and statistical analysis}

A total of 120 stomach contents were analyzed qualitatively in order to determine the main prey items for the Cynodontidae species. Whenever possible, fish prey was identified to the lowest taxonomic level and then grouped by family. Spatial niche breadth for each species $j$ was calculated using the Levins' standardized niche breadth formula (Hurlbert, 1978):

$$
B a=\frac{B-1}{N-1}
$$

Where B is Levins' niche breadth (Levins, 1968) and N is the total number of resources (sampling sites). Levin's niche breadth formula is given as follows:

$$
B=\frac{1}{\sum p i j^{2}}
$$

Where pij is the proportion of species $i$ found in the resource $j$.

Fish abundance was recorded as the total number of individual and biomass captured per unit effort (CPUE). The relative abundance of Cynodontidae species was calculated as the proportion of total CPUE (number of individuals and biomass).

Linear regressions were used to examine the relationship between Cynodontidae relative abundance and water transparency. The abundance and biomass proportions values were arcsine-transformed prior to analysis in order to meet the parametric test's assumptions. Normality and homogeneity of variances was tested using the Shapiro-Wilk and modified Levene tests, respectively. Similarity among sampling sites was determined by cluster analysis (UPGMA algorithm), based on the standardized values of biomass proportion of Cynodontidae and water transparency. Simple linear regression and cluster analysis were performed using Statistica (version 7.0, StatSoft). 




Fig. 1. Partial map of South America showing the location of the study area in the Bananal floodplain. The detailed map depicts the sampling sites (circles) in the rios Araguaia and Mortes basins. See Table 1 for site codes.

\section{Results}

A total of 509 individuals distributed among four Cynodontidae species (Hydrolycus armatus (Jardine \& Schomburgk, 1841); Hydrolycus tatauaia Toledo-Piza, Menezes \& Santos, 1999; Rhaphiodon vulpinus Spix \& Agassiz, 1829; Cynodon gibbus Spix and Agassiz, 1829) were collected at the 15 sampling sites (Table 1). Stomach content analyses indicated that all four species are strictly piscivorous. Hydrolycus armatus ingested fishes of the families Loricariidae, Arapaimidae and Callichthyidae. Rhaphiodon vulpinus and $H$. tatauaia ingested mainly Curimatidae individuals, and for C. gibbus only non-identifiable fish remains were registered.

Except for C. gibbus, all species occurred in most habitats sampled in the Bananal floodplain (Table 1), however, no species was collected at all sites. Spatial niche breadth values were low for all species, partially due to the higher abundance of Cynodontidae found in the Beleza Lake (46.4\%). Rhaphiodon vulpinus had higher niche breadth $(\mathrm{Ba}=0.256)$, followed by $H$. tatauaia $(\mathrm{Ba}=0.100), H$. armatus $(\mathrm{Ba}=0.071)$ and C. gibbus $(\mathrm{Ba}=0.021)$.

The relative abundance of Cynodontidae was positively correlated with water transparency, in relation to biomass $\left(\mathrm{r}^{2}\right.$ $=0.682, \mathrm{p}=0.0001)$ and number of individuals $\left(\mathrm{r}^{2}=0.445, \mathrm{p}=\right.$ 0.007) (Fig. 2). 
Table 1. Abundance and frequency of occurrence for Cynodontidae species, and relative abundance in biomass and number of individuals $(\mathrm{N})$ for each sampling site in the Bananal floodplain. Water transparency and coordinates are also indicated for each site.

\begin{tabular}{|c|c|c|c|c|c|c|c|c|c|}
\hline Sampling sites & Site code & H. armatus & H. tatauaia & R. vulpinus & C. gibbus & Biomass \% & $\mathrm{N} \%$ & Transp. (cm) & Coordinates \\
\hline Rio Araguaia & $\mathrm{AR}$ & 5 & 0 & 9 & 0 & 6.6 & 3.3 & 44 & $12^{\circ} 08^{\prime} 34^{\prime \prime} \mathrm{S} 50^{\circ} 40^{\prime} 12^{\prime \prime} \mathrm{W}$ \\
\hline Rio Riozinho & RI & 0 & 1 & 0 & 0 & 2.1 & 0.2 & 60 & $12^{\circ} 12^{\prime} 32^{\prime \prime} \mathrm{S} 50^{\circ} 43^{\prime} 00^{\prime \prime} \mathrm{W}$ \\
\hline Rio Cristalino & CR & 8 & 0 & 1 & 0 & 19.2 & 2.1 & 150 & $12^{\circ} 54^{\prime} 35^{\prime \prime} \mathrm{S} 50^{\circ} 49^{\prime} 39^{\prime \prime} \mathrm{W}$ \\
\hline Rio São João & SJ & 0 & 10 & 58 & 0 & 24.3 & 15.9 & 109 & $12^{\circ} 46^{\prime} 20^{\prime \prime} \mathrm{S} 51^{\circ} 06^{\prime} 36^{\prime \prime} \mathrm{W}$ \\
\hline Lago Beleza & $\mathrm{BE}$ & 74 & 63 & 72 & 27 & 31.5 & 55.3 & 230 & $12^{\circ} 55^{\prime} 50^{\prime \prime S} 50^{\circ} 48^{\prime} 18^{\prime \prime W}$ \\
\hline Lago Lagoão & LA & 5 & 0 & 0 & 0 & 2.7 & 1.2 & 21 & $13^{\circ} 00^{\prime 28 ” S} 50^{\circ} 39^{\prime 2} 22^{\prime \prime W}$ \\
\hline Lago Aruanã & $\mathrm{AU}$ & 2 & 2 & 0 & 0 & 1.9 & 0.9 & 41 & $12^{\circ} 14^{\prime} 58^{\prime \prime} \mathrm{S} 50^{\circ} 40^{\prime} 44^{\prime \prime W}$ \\
\hline Lago Melancia & ME & 1 & 5 & 5 & 1 & 5.6 & 2.8 & 61 & $13^{\circ} 40^{\prime 2} 24^{\prime \prime} \mathrm{S} 51^{\circ} 28^{\prime} 25^{\prime \prime} \mathrm{W}$ \\
\hline Lago Kênia & $\mathrm{KE}$ & 0 & 0 & 3 & 0 & 3.0 & 0.7 & 67 & $12^{\circ} 03^{\prime} 03^{\prime \prime} \mathrm{S} 50^{\circ} 41^{\prime} 49^{\prime \prime} \mathrm{W}$ \\
\hline Lago Baião & BA & 0 & 0 & 0 & 0 & 0.0 & 0.0 & 47 & $12^{\circ} 14^{\prime} 54^{\prime \prime} \mathrm{S} 50^{\circ} 43^{\prime} 42^{\prime \prime} \mathrm{W}$ \\
\hline Lago Baía da Saudade & BS & 3 & 0 & 0 & 0 & 27.7 & 0.7 & 175 & 14 $31^{\prime} 18^{\prime \prime S} 51^{\circ} 07^{\prime} 05^{\prime \prime} \mathrm{W}$ \\
\hline Lago Sucupira & SU & 2 & 2 & 34 & 1 & 29.0 & 9.1 & 123 & $12^{\circ} 25^{\prime} 47^{\prime \prime} \mathrm{S} 50^{\circ} 56^{\prime} 34^{\prime \prime W}$ \\
\hline Lago Redondo & $\mathrm{RE}$ & 1 & 5 & 5 & 1 & 9.7 & 2.8 & 112 & $13^{\circ} 41^{\prime} 10^{\prime \prime} \mathrm{S} 51^{\circ} 29^{\prime} 42^{\prime \prime} \mathrm{W}$ \\
\hline Lago Cocho & $\mathrm{CO}$ & 4 & 6 & 11 & 0 & 23.4 & 4.9 & 97 & $12^{\circ} 25^{\prime} 47^{\prime \prime} \mathrm{S} 50^{\circ} 58^{\prime} 31^{\prime \prime W}$ \\
\hline Rio das Mortes & $\mathrm{RM}$ & 3 & 9 & 69 & 1 & 11.9 & 8.73 & 70 & $12^{\circ} 31^{\prime 1} 17^{\prime \prime S} 50^{\circ} 58^{\prime} 45^{\prime \prime W}$ \\
\hline TOTAL & - & 108 & 103 & 267 & 31 & - & - & - & - \\
\hline Occurrence (\%) & - & 73.3 & 60.0 & 66.7 & 33.3 & - & - & - & - \\
\hline
\end{tabular}



Fig. 2. Linear regression between relative abundance in biomass (a) and number of individuals (b) of Cynodontidae species and water transparency from 15 sampling sites in the Bananal floodplain, Mato Grosso, Brazil.
Cluster analysis of the sampling sites based on Cynodontidae relative abundance and water transparency indicated two main groups (Fig. 3). Group A comprises habitats with less transparent waters $(<70 \mathrm{~cm}$, except Redondo lake), and within these sites the relative abundance of Cynodontidae in biomass ranged from 0 to $11.9 \%$. Group B comprises clear-water sites $(>95 \mathrm{~cm})$, with the relative abundance of Cynodontidae ranging from 19.2 to $27.7 \%$. Beleza Lake had the highest water transparency $(230 \mathrm{~cm})$ and alone represented nearly half of the total number of individuals (46.4\%) of Cynodontidae, remaining isolated from the other groups.

\section{Discussion}

The family Cynodontidae shows several morphological features that make it one of the main piscivorous fish groups in the Bananal floodplain. The turned-up mouth and the horizontal dorsal profile allow these fish be highly efficient in predation near the surface and in more illuminated layers of the water column (Winemiller, 1992; Matthews, 1998), where they hunt actively (Fink \& Fink, 1978; Keenleyside, 1979; Toledo-Piza et al., 1999). The presence of light is essential for success in obtaining food for species with these features (Keenleyside, 1979; Wooton, 1990; Melo et al., 2005).

In the Cerrado of Central Brazil and in southern Amazônia the process of deforestation for the establishment of agriculture and pastures has caused serious alterations in aquatic habitats (Williams et al., 1997; Neill et al., 2001, 2006). The removal of native vegetation can alter significantly the biogeochemical processes of soils and, as a consequence, increase the amount of particulate and dissolved material in streams (Williams et al., 1997). In the Brazilian State of Rondônia, Neill et al. (2001) found a 7-fold increase in the amount of suspended material in streams in areas of pastures 


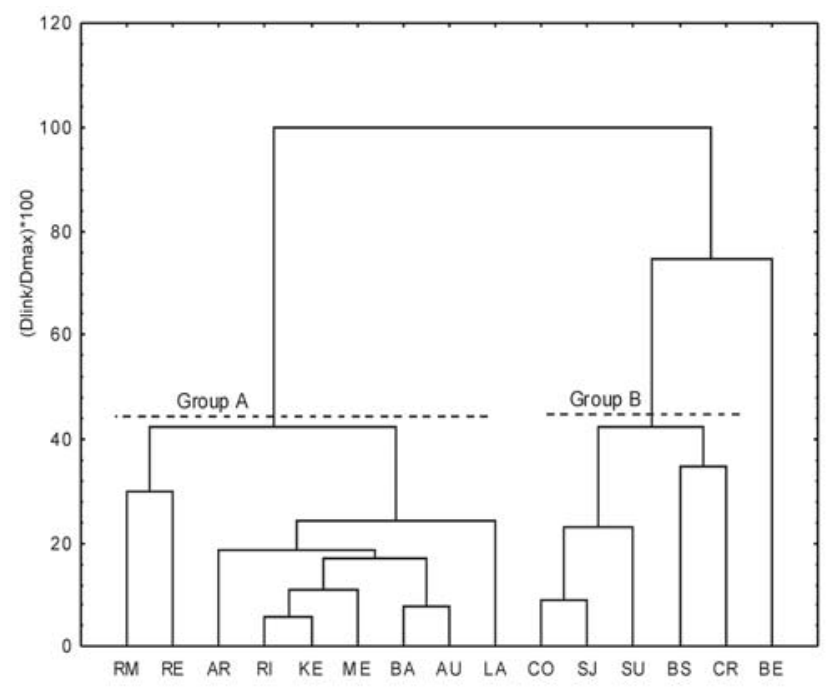

Fig. 3. Cluster dendrogram based on relative abundance in biomass of Cynodontidae species and water transparency from 15 sampling sites in the Bananal floodplain, Mato Grosso, Brazil (UPGMA algorithm, Euclidian distance). See Table 1 for site codes.

when compared with natural areas. Costa et al. (2003) demonstrated that after two decades of intense agricultural activity in the rio Tocantins basin, the drainage regime was significantly affected by the alteration of plant cover. According to the same authors, one of the most important changes is the increase in the amplitude of the flood peak. This causes a very rapid surface runoff in the basin with a greater capacity of carrying sediments to the rivers. The higher load of material originating from altered areas can also be the main reason for the increase in water turbidity, as observed by riverine populations of the Araguaia regions.

The relative abundance in weight of Cynodontidae, directly and positively correlated with water transparency, demonstrates a narrow relationship between the adaptations of these fishes and this physical characteristic of the aquatic environment. As shown by cluster analysis, similar habitats in relation to water transparency are also similar with regard to the proportional composition of Cynodontidae. In relation to niche breadth, the low values indicate that these species present high habitat specificity in the Bananal floodplain. Raphiodon vulpinus had the lower spatial niche breadth among the species, which suggest that this species is more tolerant to variations in water transparency.

Studies carried out by Tejerina-Garro et al. (1998) and Lima (2003) in lakes of the Bananal floodplain demonstrated that as water transparency changes seasonally, the relative abundance of visually and non-visually oriented fish groups changes as well. This relationship is described in the piscivorytransparency-morphometry (PTM) model (Rodriguez \& Lewis, 1997), which predicts that as water transparency decreases, the relative abundance of visually oriented taxa also decreases in relation to others adapted to low transparency conditions. Although Rodriguez \& Lewis (1997) found higher abundance of Cynodontidae in turbid floodplain lakes from the Orinoco basin, relating this pattern to potential adaptations of this group to low visibility, the results in the present study indicate the opposite. Nonetheless, transparency values found in the Orinoco floodplain lakes are much lower than those of the Bananal floodplain sites (5 to $130 \mathrm{~cm}$ in the Orinoco and 21 to 230 in the Bananal floodplain), and this difference, in addition to distinct sampling methodologies, make comparisons difficult between the two studies.

In natural environment, water transparency variations are predictable and therefore tolerated by the fishes. In areas subjected to degradation by deforestation, the transport of sediments is greater and for longer periods (Jones et al., 1999), altering the conditions of the aquatic system. In such conditions, the decrease of water transparency occurs mainly due to the waters originating from tributaries that drain large deforested areas, which leads to increased transport of sediments by surface runoff, increasing water turbidity. This increase in turbidity reduces the availability of light in the environment and alters substantially visual activities such as foraging and finding mates (Matthews, 1998; Henley et al., 2000). In addition, it is possible that higher turbidity can also be occurring through eutrophication of the aquatic habitats, due to the loading of nutrients coming from areas occupied by agriculture and ranching or due to the greater amount of light reaching the water surface due to the reduction in riparian vegetation. In the State of Rondônia, Brazil, a marked increase in chlorophyll was detected in stream waters of areas occupied by pastures, when compared to those of forested areas (Thomas et al., 2004). These alterations in transparency can be so severe to the point of inhibiting and even preventing the existence of visually oriented species in the region, as detected by Lin \& Caramaschi (2005), in a lake located in the State of Pará, Brazil.

The advance of the farming and ranching frontier in Central Brazil, without respect to the limits of deforesting imposed by environmental legislation in many cases, has caused major alterations in the landscape. These alterations are in turn acting on the aquatic habitats such that many species are eliminated from native regions, without any control or scientific study that has demonstrated their ecologic necessities and the effects of environmental damage on fishes. The preference for more transparent waters and the strictly piscivorous diet presented by the studied Cynodontidae species can represent a key factor for the elaboration management and conservation programs for fishes in the Bananal floodplain.

\section{Acknowledgements}

Funding was provided by Conselho Nacional de Desenvolvimento Científico e Tecnológico (CNPq) and Fundação de Amparo à Pesquisa do Estado de Mato Grosso (FAPEMAT). A. Leyva helped with English editing of the manuscript. 


\section{Literature Cited}

Agostinho, A. A., S. M. Thomaz \& L. C. Gomes. 2005. Conservation of the biodiversity of Brazil's inland waters. Conservation Biology, 19(3): 646-652.

Costa, M. H., A. Botta \& J. A. Cardille. 2003. Effects of large-scale changes of land cover on the discharge of the Tocantins river of Southeastern Amazonia. Journal of Hydrology, 283: 206-217.

Diegues, A. C. 2002. Povos e águas: inventário de áreas úmidas brasileiras. São Paulo, Napaub-usp, 597p.

Fearnside, P. M. 2001. Soybean cultivation as a threat to the environment in Brazil Environmental Conservation, 28(1): 23-38.

Fink, W. I. \& S. V. Fink. 1978. A Amazônia Central e seus peixes. Suplement. Acta Amazonica, 8(4): 19-42.

Goulding, M. 1980. The fishes and the forest: explorations in Amazonian Natural History. Berkeley, University of California Press, 280p.

Hamilton, S. K., S. J. Sippel \& J. M. Melack. 2002. Comparison of inundation patterns among major South American floodplains. Journal of Geophysical Research, 107: LBA 5-1/14.

Henley, W. F., M. A. Patterson, R. J. Neves \& A. D. Lemly. 2000. Effects of sedimentation and turbidity on lotic food webs: a concise review for natural resource managers. Reviews in Fisheries Science, 8(2): 125-139.

Hurlbert, S. H. 1978. The measurement of niche overlap and some relatives. Ecology, 59(1): 67-77.

Jones, E. B. D., G. S. Helfman, J. O. Harper \& P. V. Bolstad. 1999. Effects of riparian forest removal on fish assemblages in Southern Appalachian streams. Conservation Biology, 13: 1454-1465.

Keenleyside, M. H. A. 1979. Diversity and adaptation in fish behaviour. Berlin, Springer Verlag, 208p.

Klink, C. A. \& R. B. Machado. 2005. Conservation of the Brazilian Cerrado. Conservation Biology 19(3): 707-713.

Le Bourlegat, C. A. 2003. A fragmentação da vegetação natural e o paradigma do desenvolvimento rural. Pp. 1-25. In: Costa, R. B. (Org.). Fragmentação florestal e alternativas de desenvolvimento rural na região centro-oeste. Campo Grande, Ucdb, 246p.

Levins, R. 1968. Evolution in changing environments: some theoretical explorations. Princeton, Princeton University Press, 132p.

Lima, J. D. 2003. Diversidade, estrutura trófica da ictiofauna e condições limnológicas em um lago na planície inundável do rio das Mortes - MT. Unpublished M.Sc. Dissertation, Universidade Federal de Mato Grosso, Cuiabá, Mato Grosso, 110p.

Lin, D. S. C. \& E. P. Caramaschi. 2005. Responses of fish community to the flood pulse and siltation in a floodplains lake of the Trombetas River, Brazil. Hydrobiology, 545: 75-91.

Marimon, B. S. \& E. S. Lima. 2001. Caracterização fitofisionômica e levantamento florístico preliminar do Pantanal do Rio das Mortes - Araguaia, Cocalinho, Mato Grosso, Brasil. Acta Botânica Brasilica, 15(2): 213-229.

Matthews, W. J. 1998. Patterns in freshwater fish ecology. New York, Chapman and Hall, 784p.

Melo, C. E., F. A. Machado \& V. Pinto-Silva. 2003. Diversidade de peixes em um córrego de Cerrado no Brasil Central. Brazilian Journal of Ecology, São Paulo, 1 and 2: 17-23.

Melo, C. E., F. A. Machado \& V. Pinto-Silva. 2004. Feedings habits of fish from a stream in the savanna of Central Brazil, Araguaia Basin. Neotropical Ichthyology, São Paulo, 2(1): 37-44.

Melo, C. E., J. D. Lima, T. L. Melo \& V. Pinto-Silva. 2005. Peixes do Rio das Mortes: identificação e ecologia das espécies mais comuns. Cuiabá, Central de Texto e Editora Unemat, 147p.

Mittermeier, R. A., N. Myers, P. R. Gil \& C. G. Mittermeier. 1999.
Hotspots: earth's biologically richest and most endangered terrestrial ecoregions. Mexico City, Cemex/Conservation International, 420p.

Neill, C., L. A. Deegan, S. M. Thomas \& C. C. Cerri. 2001. Deforestation for pasture alters nitrogen and phosphorus in small Amazonian streams. Ecological Applications, 11(6): 1817-1828.

Neill, C., L. A. Deegan, S. M. Thomas, C. L. Haupert, A. V. Krusche, V. M. Ballester \& R. L. Victoria. 2006. Deforestation alters the hydraulic and biogeochemical characteristics of small lowland Amazonian streams. Hydrological Process, 20: 2563-2580.

Pouilly, M. \& M. A. Rodríguez. 2004. Determinism of fish assemblage structure in Neotropical floodplain lakes: influence of internal and landscape lake conditions. Pp. 243-265. In: Welcomme, R. \& T. Petr (Eds.). Proceedings of the Second International Symposium on the Management of Large Rivers for Fisheries, vol. II. Bangkok, FAO, 310p.

Pusey, B. J. \& A. H. Arthington. 2003. Importance of the riparian zone to the conservation and management of freshwater fish: a review. Marine and Freshwater Research, 54: 1-16.

Rodríguez, M. A. \& W. M. Lewis-Jr. 1997. Structure of fish assemblages along environmental gradients in floodplains lakes of the Orinoco River. Ecological Monographs, 67: 109-128.

Silva, J. M. C. \& J. M. Bates. 2002. Biogeographic patterns and conservation in the South American Cerrado: a tropical savanna hotspot. BioScience, 52(3): 225-233.

Silva, J. F., M. R. Fariñas, J. M. Felfili \& C. A. Klink. 2006. Spatial heterogeneity, land use and conservation in the cerrado region of Brazil. Journal of Biogeography, 33(3): 536-548.

Souza, M. A. A. 1994. Relação entre as atividades ocupacionais e a qualidade da água no cerrado. Pp. 189-212. In: Novaes-Pinto, M. (Org.). Cerrado: caracterização, ocupação e perspectivas. Brasília, Editora UnB, 681p.

Tejerina-Garro, F. L., R. Fortin \& M. A. Rodríguez. 1998. Fish community structure in relation to environmental variation in floodplain lakes of the Araguaia River, Amazon Basin. Environmental Biology of Fishes, 51: 399-410.

Thomas, S., C. Neill, L. A. Deegan, A. V. Krusche, V. M. Ballester \& R. L. Victoria. 2004. Influences land use and stream on particulate and dissolved materials in a small Amazonian stream network. Biogeochemistry, 68: 135-151.

Toledo-Piza, M., N. A. Menezes \& G. M. dos Santos. 1999. Revision of the neotropical fish genus Hydrolycus (Ostariophysi: Cynodontinae) with the description of two new species. Ichthyological Exploration of Freshwaters, 10(3): 255-280.

Wantzen, K. M. 2006. Physical pollution: effects of gully erosion on benthic invertebrates in a tropical clear-water stream. Aquatic Conservation, 16(7): 733-749.

Wantzen, K. M., M. F. P. Sá, A. Siqueira \& C. N. Cunha. 2006. Stream-valley systems of the Brazilian Cerrado: impact assessment and conservation scheme. Aquatic Conservation, 16(7): 713-732.

Williams, M. R., T. R. Fisher \& J. M. Melack. 1997. Solute dynamics in soilwater and groundwater in a central Amazon catchment undergoing deforestation. Biogeochemistry, 38: 303-335.

Winemiller, K. O. 1992. Ecomorphology of freshwater fishes. Research \& Exploration, 8(3): 308-327.

Wootton, R. J. 1990. Ecology of Teleost Fishes. New York, Chapman and Hall, 404p.

Accepted February 2009 Published June 17, 2009 